Peran Guru PAI... | 53

\title{
PERAN GURU PAI DALAM MENGEMBANGKAN KECERDASAN EMOSIONAL DAN SPIRITUAL SISWA DI SMK NEGERI 1 SEMARANG
}

\author{
M Chovianan Al Sabah 1 ) * \\ Susiyanto ${ }^{2)}$ \\ ${ }_{1}^{1}$ Program Studi Pendidikan Agama Islam, Fakultas Agama Islam \\ Universitas Islam Sultan Agung, Semarang \\ 2 Program Studi Pendidikan Agama Islam, Fakultas Agama Islam \\ Universitas Islam Sultan Agung, Semarang \\ *E-mail: ananshared@gmail.com
}

\begin{abstract}
The purpose of this study was to determine how the role of Islamic religious education teachers in developing emotional intelligence and spiritual intelligence of students at SMK Negeri 1 Semarang. This type of research uses qualitative descriptive research, so that the collection of data using observation, interviews, and documentation to the parties concerned. While the data analysis I use is qualitative data analysis which includes three aspects, namely: data reduction, data presentation, and drawing conclusions. The results showed that there were changes given by religious teachers to their students. Where religious teachers are able to develop between emotional intelligence and spiritual students. In addition to providing material, religious teachers also provide exemplary learning, direct their students to pray in congregation, and control the activities of their students both at school and at home.
\end{abstract}

Keywords: Teacher Role, Emotional Intelligence, Spiritual Intelligence

\begin{abstract}
Abstrak
Tujuan penelitian ini adalah untuk mengetahui bagaimana Peran guru pendidikan agama Islam dalam mengembangkan kecerdasan emosional maupun kecerdasan spiritual siswa di SMK Negeri 1 Semarang. Jenis penelitian ini menggunakan penelitian deskritiptif kualitatif, sehingga pengumpulan datanya menggunakan observasi, wawancara, dan dokumentasi kepada pihak yang bersangkutan. Sedangkan analisi data yang penulis gunakan adalah analisi data kualitatif yang meliputi tiga aspek yaitu: reduksi data, penyajian data, dan penarikan kesimpulan. Hasil penelitian menunjukan bahwa ada perubahan yang diberikan oelh guru agama kepada siswanya. Di mana guru agama mampu mengembangankan antara kecerdasan emosional dan spiritual siswanya. Selain memberikan materi, guru agama juga memberikan pembelajaran teladan, mengarahkan siswanya untuk sholat berjamaah, dan mengontrol kegiatan siswanya baik disekolah maupun di rumah.
\end{abstract}

Kata Kunci: Peran Guru, Kecerdasan Emosional, Kecerdasan Spiritual

\section{PENDAHULUAN}

Peran pendidikan di lingkungan sekolah tidak lepas dari peran seorang guru dalam proses mendidik siswanya. Di dalam UU Republik Indonesia Nomor 14 tahun 2005 menjelaskan bahwa peran guru bukan hanya sabagai pendidik saja, akan tetapi peran ialah mendidik, mengajar, membimbing, mengarahkan, melatih, menilai, dan mengevaluasi peserta didik pada pendidikan anak usia dini jalur pendidikan formal, 
pendidikan dasar, dan pendidikan menengah (Undang - undang RI Tentang Guru dan Dosen, No. 14 thn 2005).

Tujuan pendidikan Indonesia untuk mengembangkan manusia Indonesia dan mencerdaskan kehidupan bangsa. Manusia yang mempunyai takwa dan iman kepada Tuhan yang Maha Esa dan mempunyai budi pekerti yang luhur, mandiri, kepribadian yang mantap, kesehatan rohani, dan jasmani, keterampilan dan pengetahuan, dan terakhir mempunyai rasa tanggung jawab untuk berbangsa dan bermasyarakat.

Dari berbagai macam hasil penelitian, banyak diantaranya terbukti bahwa kecerdasan emosional berperan sangat penting dan jauh lebih significant disbanding dengan kecerdasan intelektual. Kecerdasan intelektual hanya sebagai syarat dalam meraih keberhasilan, akan tetapi kecerdasan emosilah yang banyak terbukti bahwa seseorang dalam dapat lebih mudah meraih kesuksesan. Dalam hal ini juga banyak kasus terjadi bahwa kecerdasan intelektual yang tinggi jika tidak diimbangi dengan kecerdasan emosional yang bagus, maka hasilnya akan tidak maksimal. Dan sebaliknya, orang yang memiliki kecerdasan intelektual biasa saja dia mampu bersaing didalam dunia kerja. Disinlah peran kecerdasan emosional terbukti hasilnya (Agustian, 2001, p. 17).

Kecerdasan spiritual adalah kemampuan untuk memberi makna ibadah terdapat setiap perilaku, tindakan dan kegiatan melalui langkah-langkah dan pemikiran yang bersifat fitrah, menuju manusia seutuhnya, manusia yang enderung pada kebenaran (hanif) dan memiliki pola pemikiran yang tauhid (integralistik). Serta berperinsip setiap kejadian hanya karena Allah (Ginanjar, 2001, p. 57). Kecerdasan spiritual ini sangat membantu dalam membangkitkan ethos kerja (selera kerja). Ethos kerja yang tinggi membantu menyelesaikan kerja dengan baik.

Pada prinsipnya di dalam dunia pendidikan, dalam proses pembelajaran seorang guru seharunya tidak hanya mementingkan kecerdasan IQ saja pada sisiwa, tetapi juga memmperhatikan, menumbuhkan serta mengembangkan kecerdasan emosional dan spiritual (ESQ) pada siswa. Sehingga dapat menghasilkan lulusan-lulusan yang tidak hanya berintelektual tinggi, tetapi dapat menghasilkan lulusan yang berintelektual tinggi, berwawasan luas, beretika moral dan mempunyai spiritual yang tinggi. 


\section{METODE}

Penelitian ini merupakan jenis penelitian lapangan (field research), karena peneliti langsung terjun ke lapangan (tempat penelitian) untuk mendapatkan data yang diperlukan dalam penyusunan laporan penelitian. Jenis data yang dilakukan dalam penelitian ini adalah data kualitatif yang mana data yang disajikan dalam bentuk kata verbal bukan dalam bentuk angka (Muhadjir, 1996), meliputi: sejarah singkat berdirinya sekolah ini, letak geografis, visi dan misi, struktur organisasi, dan lain-lain.

Untuk memperoleh data penelitian penulis menggunakan metode sebagai berikut:

1) Metode Observasi

Metode observasi adalah suatu pengamatan dan pencatatan dengan sistematis fenomena-fenomena yang diselidiki baik secara langsung atau tidak langsung. (Ali, 1982, p. 83) Metode ini penulis gunakan untuk menghimpun data yang berhubungan dengan peneitian tentang peran guru PAI dalam mengembangkan kecerdasan emosional dan spiritual pada siswa di SMK Negeri 1 Semarang.

2) Metode Interview

Metode interview adalah metode pengumpulan data dengan jalan sepihak yang dikerjakan secara sistematis dan berdasarkan pada tujuan penelitian. (Hadi, 1991, p. 193) Metode ini digunakan untuk mengadakan wawancara langsung dengan kepala sekolah dan beberapa guru PAI untuk memperoleh data tentang gambaran umum situasi dan kondisi sekolah SMK Negeri 1 Semarang yang meliputi letak geografis, struktur organisasi, keadaan guru dan siswa, Administrasi sekolah dan lain sebagainya.

3) Metode Dokumentasi

Metode dokumentasi adalah metode yang digunakan untuk memperoleh data yang berupa catatan, transkrip, buku, surat kabar, majalah, prasasti, notulen rapat, lengger dokumen, dan sebagainya. (Arikunto, 2009, p. 131) Metode ini digunakan untuk menghimpun data yang berkaitan dengan berbagai hal yang bersifat dokumentatif berupa catatan, buku, arsip, dan lainnya sebagai data pelengkap. 


\section{HASIL DAN PEMBAHASAN}

Secara umum, ada empat peran guru PAI, di antaranya adalah:

1. Mengembangkan kecerdasan emosional dan spiritual siswa

Dalam proses mengembangkan kecerdasan emosional maupun spiritual guru PAI berupaya mensosialisasikan nilai-nilai ajaran agama. Dimana nilai-nilai ajaran agama tersebut dapat diterima oleh peserta didik, sehingga dapat di amalkan peserta didik baik didalam lingkungan sekolah maupun keluarga. Seperti halnya yang erkaitan dengan akhlakul karimah kepada orang tua, guru, maupun teman-temannya

Kegiatan yang dilakukan untuk mengembangkan kecerdasan emosional maupun spiritual seperti memberikan tauladan kepada siswa untuk sopan santun, melakukan bakti sosial, memberikan sedekah kepada orang yang membutuhkan, rohis sebagai kegiatan berinteraksi emosional maupun spiritual, sholat berjamaah di masjid. Kegiatan seperti di atas merupakan bagaimana guru PAI dalam mengembangkan kecerdasan emosional maupun spiritual kepada peserta didik.

2. Evaluator dalam mengevaluasi kecerdasan emosional dan spiritual siswa

Setiap pembelajaran maupun melakukan kegiatan lainya guru PAI berupaya mengevaluasi. evaluasi mempunyai tujuan sebagai tolak ukur apakah kegiatan pembelajaran sudah dilakukan secara maksimal atau belum. Evaluasi juga bertujuan apakah proses belajar sudah sampai pada tujuan pembelajaran. Kegiatan evaluasi biasnya dilakukan guru setelah memberikan materi kepada peserta didiknya. Seperti halnya menanyakan kembali pelajaran atau materi yang sudah disampaikan oleh guru PAI.

3. Mengarahkan kecerdasan emosional dan spiritual siswa

Sesuai dengan peran guru dalam mengembangkan kecerdasan emosional maupun spiritual, guru PAI akan mengarahkan peserta didik dengan mewajibkan mengikuti kegiatan-kegiatan yang ada di sekolah. Seperti kegiatan sholat dhuha, sholat berjamaah, bakti sosial, membantu sesama teman. Semua kegiatan yang dilakukan oleh guru PAI bertujuan sebagai mengarahkan peserta didik untuk bisa dikembangkan dalam kecerdasan emosiol dan spiritual.

4. Menghadapi dan mengelolah peserta didik yang bermaslah dalam proses belajar di sekolah. 
Selain mengajar atau mendidik, salah satu tugas guru PAI adalah sebagai penanganan ketika peserta didik mendapatkan masalah dalam proses belajar. Hal ini telah dilakukan oleh guru PAI di SMK Negeri 1 Semarang saat menjumpai peserta didik yang bermasalah. Dimana siswa yang kedapatan membolos atau tidak mengikuti pelajaran akan ditangani langsung.

Guru PAI kemudian mengambil tindakan yang bisa membuat peserta didik yang kepatan masalah supaya tidak mengulangi kembali kesalahanya. Contohnya guru memberikan tugas kepada peserta didik untuk membersihkan masjid, membantu tugas kebersihan sekolah untuk menyapu lapangan. Penanganan seperti dapat merubah peserta didik yang kedapatan bermasalah.

\section{Faktor Pendukung dan Penghambat}

Faktor pendukung dalam mengembangkan kecerdasan kecerdasan emosional dan spiritual pada siswa adalah:

a. Siswa antusias dalam menerima pelajaran maupun kegiatan praktek ibadah

b. Sarana dan prasarana yang memadai dan mendukung saat proses belajar siswa.

c. Adanya dukungan kebijakan dari pihak sekolahan, sehingga mempermudah guru dalam mengembangkan kecerdasan emosional maupun spiritual.

Dalam proses belajar mengajar tentu ada faktor penghambat dalam mengembangkan kecerdasan emosional maupun spiritual. Di antaranya adalah:

a. Guru tidak mendapat dukungan penuh dari pihak orang tua atau keluarganya

b. Kurangnya waktu berinteraksi saat proses belajar, sehingga pelajaran tidak bisa disampaikan secara maksimal.

c. Kurangnya motivasi dari orang tua dalam belajar

d. Kurang kontrolnya orang tua dan guru dalam pergaulan siswa, sehingga mereka merasa bebas dalam pergaulan.

\section{KESIMPULAN}

Berdasarkan hasil penelitian penulis yang berkaitan dengan judul peran guru PAI dalam mengembangkan kecerdasan emosional dan spiritual siswa di SMK Negeri 1 Semarang. Maka penulis dapat menyimpulkan bahwa peran dimana guru PAI harus mampu mengembangkan setiap kecerdasan emosional maupun spiritual. Tugas guru tidak hanya mengajar saja, akan tetapi tugas guru juga bisa mengevalusai proses belajar peseta didik. Sehingga dapat menjadi acuan apakah peserta didik berkembang 
secara emosional maupun spiritual. Selain itu, guru harus mampu mengarahkan peserta didik dalam suatu kegiatan, yang dimana kegiatan tersebut sebagai jembatan dalam kecerdarsan emosional dan spritualnya. Terakhir, ketika ada peseta yang bermasalah guru harus mampu menghadapi menangani, guru juga mampu mengetahui masalah yang ada pada peserta didiknya agar dapat mengembangkan kecerdasan emosional maupun spritualnya.

\section{DAFTAR PUSTAKA}

Agustian, A. G. (2001). Rahasia Sukses Membangun Kecerdasan Emosi Dan Spiritual ESQ. Jakarta: PT Arga Tilanta.

Agustin, A. G. (2008). Rahasia Sukses Membangun Kecerdasan Emosi dan Spiritual. Jakarta: AGRA Publishing.

Agustine, A. G. (2008). Rahasia Sukses Membangun Kecerdasan Emosi dan Spiritual ESQ. Jakarta: ARGA Publishing.

Ali, M. (1982). Penelitian Kependidikan Prosedur dan Strategi. Bandung: Aksara Baru.

Arikunto, S. (2009). Dasar-dasar Evaluasi Pendidikan. Jakarta: Bumi Aksara.

Daudiah, I. (2013). Hubungan Spiritual Quotient (Kecerdasan Spiritual) dengan Kenakalan Remaja Pada Siswa. Jurnal Psikologi, 33.

Goleman, D. (2002). Emotional Intelligence. Jakarta: PT Gramedia Pustaka Utama.

Hadi, S. (1991). Statistik. Jakarta: Pustaka Pelajar.

Kartono, K. (2009). Rajawali Pres. Depok: Pemimpin dan Kepemimpinan.

Kistoro, H. C. (2004). Kecerdasan Emosional Dalam Pendidikan Islam. 6.

Kurniasih, I. (2010). Mendidik SQ Anak Menurut Nabi Muhammad SAW. Yogyakarta: Pustaka Marwa.

Meriyati. (2014). Peran Orang Tua Dalam Mengembangkan Kecerdasan Anak. 34. 
Implementasi Metode Iqro'... | 59

\title{
IMPLEMENTASI METODE IQRO' DALAM PEMBELAJARAN MEMBACA AL- QUR'AN
}

\author{
Tsaqifa Taqiyya Ulfah 1 ) * \\ Muhammad Shaleh Assingkily ${ }^{2)}$ \\ Izzatin Kamala ${ }^{3)}$ \\ ${ }^{1}$ Program Studi Pendidikan Guru Madrasah Ibtidaiyah,
Universitas Islam Negeri Sunan Kalijaga Yogyakarta \\ 2 Program Magister Pendidikan Guru Madrasah Ibtidaiyah, \\ Universitas Islam Negeri Sunan Kalijaga Yogyakarta \\ 3 Program Studi Pendidikan Guru Madrasah Ibtidaiyah, \\ Universitas Islam Negeri Sunan Kalijaga Yogyakarta \\ *E-mail: tsaqifa.taqiyya28@gmail.com
}

\begin{abstract}
The purpose of this research is to describe implement the Iqro' method which learning to read the Qur'an at TKA-TPA "AMM" Kotagede Yogyakarta, to explain the systematic, and advantage the Iqro' method. The research uses the type of qualitative research by describing the data that has been collected as research and field research as a place of research. The results of this research are the implementation of the Iqro' method which learning to read the Qur'an at TKA-TPA "AMM" Kotagede Yogyakarta based on the main principles of classical and private. Other principles such as, directly introduce the sound of hijaiyah, for kindergarten age are allowed to read, CBSA system, and teaching have a purpose. Systematic Iqro' method which learning to read the Qur'an through stage start from volumes 1-6. Iqro' method is arrange from concrete to abstract, start from easy to difficult, and start from simple to complex. The Iqro' method has advantage, that has been applied throughout Indonesia and some ASEAN countries, flexible, the books are easy to obtain and affordable, use the CBSA system, can finish Iqro' with a short time, practical, systematic, and varied.
\end{abstract}

Keywords: Iqro' method, Learning to Read the Qur'an

\begin{abstract}
Abstrak
Tulisan ini bertujuan mendeskripsikan historistas dan implementasi metode Iqro' dalam pembelajaran membaca Al-Qur'an di TKA-TPA “AMM” Kotagede Yogyakarta dengan mengkaji bagaimana implementasi, sistematika dan kelebihan metode Iqro' AMM Kotagede Yogyakarta. Untuk itu, pendekatan kualitatif tepat digunakan dalam penelitian ini melalui observasi, wawancara dan dokumentasi. Hasil penelitian ini menunjukkan (1) metode Iqro' diimplementasikan secara klasikal, privat, mengenalkan bunyi huruf hijaiyah, membaca langsung Iqro' "versi" AMM dan sistem CBSA; (2) Sistematika metode Iqro' dalam pembelajaran membaca Al-Qur'an melalui tahapan-tahapan mulai dari jilid 1-6 yang disusun oleh pihak AMM Kotagede Yogyakarta dimulai dari yang sederhana menjadi kompleks; dan (3) Metode Iqro' memiliki kelebihan yaitu sudah diterapkan di seluruh Indonesia dan sebagian Negara ASEAN, fleksibel, buku ajar nya mudah didapatkan dan harganya terjangkau, menggunakan sistem CBSA, dapat khatam Iqro' dengan waktu yang singkat, praktis, sistematis, dan variatif.
\end{abstract}

Kata Kunci: Metode Iqro', Pembelajaran Membaca Al-Qur'an 
60 | Tsaqifa Taqiyya Ulfah, Muhammad Shaleh Assingkily, \& Izzatin Kamala

\section{PENDAHULUAN}

Al-Qur'an merupakan kalamullah (Ilyas, 2013: 16) yang mengandung sumber ajaran Islam (Farkhan, 2019: 2), hikmah (Durriyah, 2016: 1), sebagai pedoman dan petunjuk hidup bagi manusia (Hermawan, 2018: 27-35). Bahkan, membacanya dihitung ibadah dan memperoleh pahala dari Allah swt. (Siregar, 2018: 1-28) Untuk itu, penting mempelajari dan memahami kaidah bacaan yang berlaku (Yusuf, 2017: 209-233), dikenal dengan istilah ilmu tajwid. Pembelajaran membaca al-Qur'an dalam perkembangannya dilaksanakan dalam berbagai bentuk kegiatan, termasuk pengajian anak-anak. Untuk itu, dikembangkan pula berbagai metode pengajian yang mudah dipahami dan dipelajari anak.

Pengajian anak-anak era saat ini, masih mengalami beberapa kendala dalam efektivitas pelaksanaannya, yakni minimnya anak muda sebagai guru mengaji di pedesaan (Nadliyah, 2018: 719-736), sistem pengelolaan pengajian (Sauri, 2013, Kulsum, 2019: 124-126), metode yang diajarkan (Kartika \& Nurman, 2018: 141-148), kecanggihan teknologi yang mengurangi minat mengaji generasi muda dan anak-anak (Pangastuti, 2017: 165-174), pembiayaan (Malik, 2013: 387-404), dan perhatian pemerintah yang masih rendah terhadap pengajian anak-anak (Maya, et.al, 2018: 7592).

Mengamati kondisi tersebut, metode belajar di pengajian anak-anak berupa TPQ menjadi hal penting dalam menunjang kemampuan anak belajar al-Qur'an. Seiring berjalannya waktu banyak ide-ide yang bermunculan untuk melakukan pembaharuan metode, guna mempemudah dalam membaca Al-Qur'an. Salah satunya yaitu pelopor gerakan pembelajaran membaca Alqur'an yang bernama KH.As'ad Humam.

KH. As'ad Humam menghimpun kawan-kawannya dan kumpulan mahasiswa dalam suatu perkumpulan yaitu Team Tadarus Angkatan Muda Masjid dan Mushola (Team Tadarus "AMM") Yogyakarta. Yayasan Team Tadarus "AMM" mendirikan Taman Kanak-kanak Al-Qur'an (TKA) "AMM” dan Taman Pendidikan Al-Qur'an (TPA) "AMM" setelah melakukan studi banding dan uji coba.

Selain mendirikan TKA-TPA “AMM”, KH. As'ad Humam juga mencetuskan metode cepat dalam membaca Al-Quran yang bernama "Metode Iqro". Metode ini sudah diterapkan hampir di seluruh wilayah Indonesia. Bahkan, sebagian Negara ASEAN juga menggunakan metode tersebut sebagai sarana dalam membaca Al-Qur'an. Hal tersebut membuktikan bahwa metode Iqro' sudah dipercaya oleh pihak dalam negeri maupun 
luar negeri yang berperan dalam proses pembelajaran membaca Al-Qur'an (Budiyanto, 2019: 6-9).

Metode iqro' yang dipelopori KH. As'ad Humam menarik dikaji secara mendalam sebagai metode lokal yang dapat mengglobal dalam pembelajaran Al-Qur'an bagi anakanak. Untuk itu, fokus penelitian ditujukan pada sistematika dan implementasi metode iqro’ di Kotagede Yogyakarta.

\section{METODE}

Penelitian ini termasuk penelitian lapangan (field research). Peneliti melakukan penelitian lapangan yang bertempat di TKA-TPA “AMM" Kotagede Yogyakarta. Jenis penelitian ini termasuk penelitian kualitatif. Penelitian kualitatif merupakan penelitian yang digunakan untuk meneliti suatu hal yang berdasarkan fakta-fakta yang ditemukan di lapangan (Suryana, 2010: 37). Penelitian kualitatif akan menghasilkan data deskriptif berupa catatan tertulis atau lisan dari narasumber yang bersangkutan (Marlita, 2015: 15). Peneliti menggali data menggunakan teknik wawancara. wawancara mendalam, observasi dan dokumentasi.

\section{HASIL DAN PEMBAHASAN}

\section{A. Implementasi Metode Iqro' dalam Pembelajaran Membaca Al-Quran}

Penelitian ini dilakukan di Balai Litbang LPTQ Nasional Yayasan Team Tadarus "AMM" bagian TKA-TPA yang terletak di Kampung Selokraman, Kelurahan Purbayan, Kotagede, Kota Yogyakarta, DIY. Peneliti mendapat informasi dari narasumber yang bernama Mahsun Abdus Salam melalui wawancara bahwa "AMM" merupakan singkatan dari Angkatan Muda Masjid Mushola. Team Tadarus "AMM" bermula dari sebuah perkumpulan kawan-kawan K.H As'ad Humam dan kumpulan mahasiswa. Kemudian mereka mendirikan TKA-TPA "AMM", beberapa saat kemudian Menteri Agama mengesahkan TKA-TPA “AMM” sebagai Balai Penelitian dan Pengembangan Sistem Baca Tulis Al-Qur'an LPTQ Nasional. (Wawancara, Mahsun Abdus Salam, tanggal 28 Oktober 2019)

Adapun visi dan misi Balai Litbang LPTQ Nasiomal Yayasan Team Tadarus "AMM" antara lain:

1. Visi Balai Litbang LPTQ Yayasan Team Tadarus "AMM" adalah menjadi penerus dan penyempurna gerakan dakwah Al-Qur'an yang profesional dalam skala 
Nasional (Indonesia) dan Regional (ASEAN) bagi terwujudnya masyarakat dunia yang Qur'ani sebagai Rahmatan Lil'Alamin.

2. Misi Balai Litbang LPTQ Naisonal Yayasan Team Tadarus "AMM" antara lain:

a. Mengoptimalkan fungsi sebagai Balitbang LPTQ Nasional.

b. Meningkatkann kualitas Lembaga TKA/TPA/TQA sebagai percontohan/model Nasional.

c. Merevitalisasi metode Iqro' sebagai sumber pembelajaran Al-Qur'an bagi segala tingkat dan kalangan.

d. Membangun Pusdiklat Nasional untuk penyediaan SDM yang berkualitas bagi gerakan dakwah Al-Qur'an.

e. Menyediakan forum informasi dan konsultasi bagi aktivis dakwah AlQur'an melalui Telepon, Sms, Mailing List, dan Website, serta Terbitan berkala.

f. Menjadi penerbit buku-buku pendukung dakwah Al-Qur'an. (Dokumentasi, Balitbang LPTQN Team Tadarus AMM, 28 Oktober 2019)

Berdasarkan hasil penelitian, Balai Litbang LPTQ Nasional Yayasan Team Tadarus "AMM" mengelompokkan pembelajaran Al-Quran menjadi 3 jenjang yaitu TKA-TPA, TKAL-TPAL, dan TQA untuk mempermudah dalam pembelajarannya. TKA-TPA merupakan pendidikan Al-Quran yang sederajat. TKA (Taman Kanakkanak Al-Qur'an) merupakan lembaga pendidikan Al-Quran untuk anak-anak TK yang berumur antara 4-6 tahun. Sedangkan TPA (Taman Pendidikan Al-Qur'an) adalah lembaga pendidikan Al-Qur'an untuk anak-anak SD yang beumur antara 712 tahun. Disini santri diajarkan bagaimana cara membaca Al-Qur'an dengan metode Iqro'.

TKAL (Taman Kanak-Kanak Lanjutan) merupakan lembaga lanjutan dari TKA. Sedangkan TPAL (Taman Pendidikan Al-Qur'an Lanjutan) merupakan lembaga lanjutan untuk TPA. Di jenjang ini, santri sudah harus dapat membaca Al-Quran (Wawancara, Mahsun Abdus Salam, tanggal 28 Oktober 2019). Dan jenjang yang terakhir adalah TQA yang merupakan lembaga pendidikan setelah TKAL-TPAL (Budiyanto, et.al, 2003: 4). TQA merupakan singkatan dari Ta'limul Qur'an Lilaulad (Budiyanto, et.al, 2008: 22).

TQA bertujuan untuk membimbing anak-anak agar dapat membaca, memahami Al-Qur'an, dan mengamalkannya di kehidupan sehari-hari. TQA dibagi 
menjadi dua yaitu TJA dan TFJA. TJA merupakan singkatan dari Tahfidz Juz Amma. Sedangkan, TFJA merupakan singkatan dari Takhfim Juz Amma. Di setiap jenjang, santri menempuh pendidikannya selama 1 tahun. (Wawancara, Mahsun Abdus Salam, tanggal 28 Oktober 2019)

Materi yang diajarkan terdapat materi pokok dan materi penunjang. Materi pokok berupa belajar membaca Al-Qur'an dengan menggunakan Iqro jilid 1-6. Jika sudah lulus iqro, maka dilanjutkan mulai Al-Qur'an juz 1. Materi penunjang yang digunakan adalah hafalan bacaan sholat, doa sehari-hari, surat-surat pendek, hafalan ayat-ayat pilihan, dasar-dasar ulumul qur'an, menulis huruf-huruf AlQur'an, dan BCM (Bermain cerita dan Menyanyi). (Humam, et.al, 2001: 11-14)

Berdasarkan hasil penelitian, pembelajaran membaca Al-Qur'an di TKA-TPA "AMM" dilaksanakan setiap hari selain hari Jum'at yang dibagi menjadi dua sesi. Sesi pertama pembelajaran dilaksanakan pada siang hari, sedangkan sesi kedua pembelajaran dimulai pada sore hari. Pembelajaran dimulai dengan pembukaan, bacaan sholat, doa sehari-hari, belajar membaca Al-Qur'an dengan metode Iqro', latihan menulis huruf hijaiyah, pembelajaran akidah akhlak melalui sistem BCM (Bermain, Cerita, dan Menyanyi), dan diakhiri dengan penutup. (Wawancara, Mahsun Abdus Salam, tanggal 28 Oktober 2019)

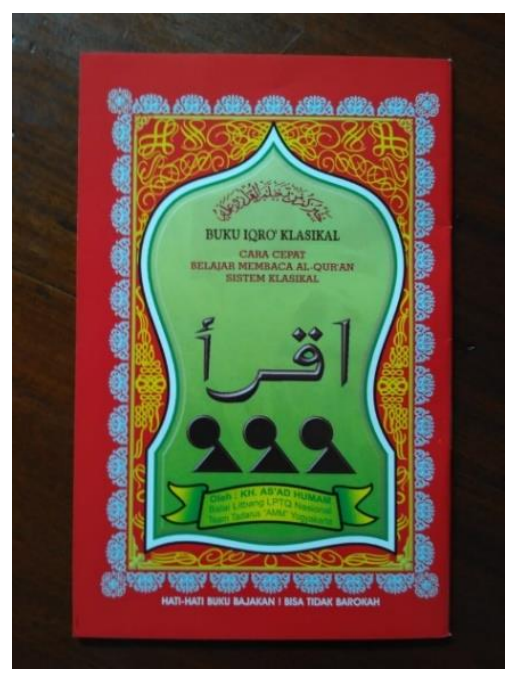

Gambar 1. Buku Iqro' Klasikal Team Tadarus “AMM” Yogyakarta

(Dokumentasi: Tsaqifa, 28 Oktober 2019)

Pembelajaran membaca Al-Qur'an diajarkan oleh ustadz/ah di TKA-TPA "AMM" melalui metode Iqro' sesuai dengan sifat-sifat buku Iqro'sebagai berikut: 1) Bacaan Langsung, 2) CBSA (Cara Belajar Siwa Aktif), 3) Privat/Klasikal, 4) Modul, 5) 
64 | Tsaqifa Taqiyya Ulfah, Muhammad Shaleh Assingkily, \& Izzatin Kamala

Asistensi, 6) Praktis, 7) Sistematis, 8) Variatif, 9) Komunikatif, 10) Fleksibel. (Humam, 1990)

Berdasarkan sifat buku Iqro' di atas, bahwa pembelajaran membaca AlQur'an di TKA-TPA “AMM" dilakukan secara privat dan klasikal. Cara privat dilakukan dengan cara menyimak santri secara bergantian. Cara privat yang dilakukan saat mengajar menggunakan cara sebagai berikut:

1. Metode pembelajaran dengan cara meniru. Dalam cara ini, ustadz/ah memberikan contoh-contoh bacaan yang benar kemudian santri menirukannya.

2. Untuk melatih makhrojul huruf santri, pembelajaran dilakukan dengan cara santri melihat gerak bibirnya ustadz/ah dan ustadz/ah juga melihat bagaimana gerak-gerik bibir santri.

3. Metode pembelajaran dengan cara ustadz mempergunakan ucapan jelas dan komunikatif. Dalam cara ini, ustadz/ah menyimak bacaan santri dan disisipkan dengan motivasi atau komentar yang membangun.

4. Ustadz mengajukan pertanyaan dan anak-anak menjawabnya.

Adapun cara klasikal diterapkan oleh ustadz/ah dengan cara berdiri di depan santri menjelaskan materi dengan buku panduan klasikal. Buku panduan Iqro' klasikal ini hampir sama dengan buku Iqro' yang biasa. Namun buku klasikal cenderung lebih tipis karena jumlah latihan untuk membaca lebih sedikit (Wawancara, Mahsun Abdus Salam, tanggal 28 Oktober 2019).

Menurut peneliti, penerapan metode Iqro' dalam pembelajaran membaca AlQur'an di TKA-TPA “AMM” telah sesuai dengan sifat buku Iqro'. Selain itu, ustadz/ah di TKA-TPA “AMM" sangat berkualitas dan profesional. TKA-TPA “AMM” memiliki ustadz/ah yang mayoritas berpendidikan S1 dan wajib memiliki sertifikat syahadah satu setelah melakukan pelatihan. Maka dari itu, sudah pantas jika pembelajaran membaca Al-Qur'an disini berjalan dengan lancar dan sukses. Pembelajaran yang sukses dapat menghasilkan santri yang berkualitas dan pandai dalam membaca AlQur'an sesuai makhrojul huruf.

\section{B. Sistematika Metode Iqro'}

Pembelajaran membaca Al-Qur'an di TKA-TPA "AMM" menggunakan metode Iqro' sebagai materi pokok. Metode iqro yang digunakan dimulai dari jilid 1-6. Berikut ini merupakan isi materi metode Iqro' jilid 1-6: 


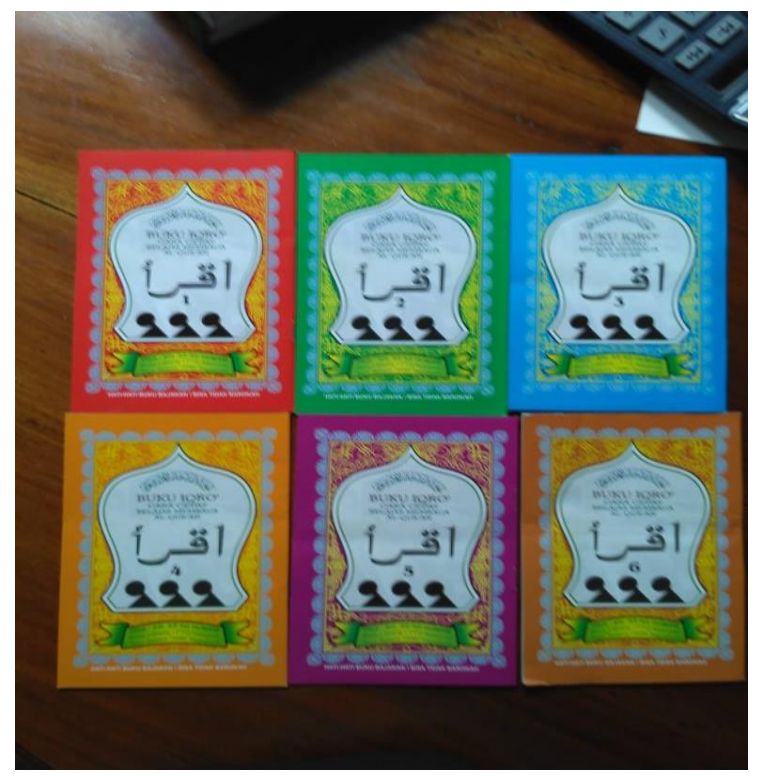

Gambar 2. Iqro' Jilid 1-6 Team Tadarus “AMM” Yogyakarta

(Dokumentasi: Tsaqifa, 28 Oktober 2019)

\section{Iqro' Jilid 1}

Materi jilid 1 berisi tentang pengenalan huruf-huruf tunggal yang berharokat fathah. Diawali dengan huruf $a-b a, b a-t a,-t s a$ dan seterusnya. Jilid 1 ini bertujuan agar santri dapat membaca dan mengucapkan huruf hijaiyah secara fasih yang sesuai dengan makhroj huruf tunggal yang berfathah. Selain itu, anak-anak dapat membedakan bunyi huruf yang memiliki makhroj yang berdekatan seperti antara huruf $a$ dengan huruf ' $a$, antara huruf sa dengan sya, antara huruf $s a$ dengan $t s a$, dan lain sebagainya.

\section{Iqro' Jilid 2}

Materi pada jilid 2 berisi tentang bunyi huruf-huruf bersambung berharokat fathah, bacaan "mad" (panjang). Jilid 2 bertujuan meningkatkan kefasihan membaca bunyi huruf, dapat membaca huruf-huruf sambung, dapat membedakan bacaan panjang dan pendek.

\section{Iqro'Jilid 3}

Materi pada jilid 3 memperkenalkan bacaan panjang karena diikuti ya' sukun dan kasroh panjang karena berdiri, bacaan dlommah panjang karena diikuti wawu sukun dan dlommah panjang karena terbalik, mengenal nama tanda baca fathah, kasroh, dlommah, dan sukun, dan yang terakhir dapat mengenal namanama huruf alif, ya', dan wawu. 


\section{Iqro' Jilid 4}

Materi pada jilid 4 berisi tentang pengenalan nama-nama huruf hijaiyah dan tanda baca. Jilid 4 berawal dengan bacaan fathah tanwin, kasroh tanwin, dlommah tanwin, bunyi ya' sukun, dan wawu sukun yang jatuh setelah harokat fathah, mim sukun, nun sukun, dan qolqolah. Dalam mempelajari tanda baca tanwin, dapat mempekenalkan kepada santri tentang bacaan-bacaan idzhar.

\section{Iqro' Jilid 5}

Materi iqro jilid 5 berisi tentang pengenalan cara membaca alif-lam qomariyah, tanda waqof, mad far'i, alif lam syamsiyah, nun sukun/tanwin bertemu hurufhuruf idghom bighunnah dan bilaghunnah, dan yang terakhir adalah cara membaca lam dalam lafadzh jalalah.

\section{Iqro' Jilid 6}

Materi iqro jilid 6 berisi tentang pengenalan cara membaca nun sukun atau tanwin bertemu dengan huruf-huruf idghom bighunnah, iqlab, ikhfa'. Selain itu, berisi tentang cara membaca dan pengenalan tanda waqof, cara membaca waqof pada beberapa huruf musykilat, dan cara membaca huruf-huruf dalam fawaithussuwar. Jika metode Iqro' sudah diterapkan dari jilid 1 sampai 6, santri dapat melanjutkan Al-Quran. (Budiyanto, 1995: 9-14)

Berdasarkan penjelasan di atas, dipahami bahwa pembelajaran melalui sistematika mulai iqro' jilid 1 hingga jilid 6 memberi kemudahan siswa secara perlahan belajar al-Qur'an. Sehingga dipandang tepat setiap tingkatan yang dilalui anak semakin memotivasi mereka dalam belajar al-Qur'an.

\section{Kelebihan Metode Iqro' dalam Pembelajaran Al-Qur'an}

Pembelajaran Al-Qur'an metode Iqro' memiliki kelebihan antara lain:

1. Metode Iqro' sudah diterapkan di seluruh penjuru Indonesia dan sebagian Negara ASEAN seperti Malaysia dan Thailand.

2. Buku penunjang (buku Iqro') mudah didapatkan dimana saja dan harganya sangat terjangkau.

3. Menggunakan sistem CBSA (Cara Belajar Siswa Aktif).

4. Metode Iqro' fleksibel dalam peningkatan jilid. Jika santri sudah mengeluarkan kemampuan dengan maksimal namun belum dapat membaca huruf hijaiyah 
tertentu misal santri selalu terbalik dalam mengucapkan huruf $b a$ dan $n a$. Namun ketika santri dimohon untuk membaca huruf yang lain ternyata bisa, maka santri dapat dinaikkan ke tingkat jilid selanjutnya.

5. Dalam waktu 6-8 bulan santri TKA-TPA dapat khatam Iqro' dan melanjutkan ke tingkat Al-Qur'an walau membacanya masih pelan.

6. Praktis, karena ustadz/ah langsung dapat memahami kemampuan santri.

7. Metode Iqro' bersifat sistematis, disusun berdasarkan kemampuan yang berbeda. Metode Iqro' disusun dari yang konkret menuju abstrak, diawali dari yang mudah menuju sulit, dan dimulai dari yang sederhana menjadi kompleks.

Variatif dengan modul yang berbeda dan warna yang menarik. Selain mudah dalam melakukan pembelajaran Al-Qur'an, Iqro' memiliki variasi modul dan memiliki warna yang bermacam-macam sehingga santri tertarik dalam membaca dan tidak bosan (Wawancara, Mahsun Abdul Salam, tanggal 28 Oktober 2019).

\section{SIMPULAN}

Berdasarkan hasil penelitian, dapat disimpulkan bahwa implementasi metode Iqro' di TKA-TPA “AMM” berdasarkan prinsip utama yang dimiliki yaitu melakukan pembelajaran membaca Al-Qur'an dengan privat dan klasikal. Dalam metode Iqro, santri diperkenalkan tentang huruf hijaiyah yang terdapat dalam jilid 1-6. Dimulai dari konkret menjadi abstrak, dari mudah menjadi sulit, dan dari sederhana menuju kompleks.

Sesuai dengan metode Iqro' pembelajaran yang dilakukan menekankan bahwa santri diprioritaskan untuk bisa membaca dahulu , baru mengenal istilah lainnya.. Dalam Pembelajaran, "TKA-TPA AMM" menerapkan BCM (Bermain, Cerita, dan Menyanyi). TPA-TKA “AMM” menerapkan pembelajaran Al-Qur'an sesuai dengan sifat metode Iqro' yaitu bacaan langsung, CBSA (Cara Belajar Siwa Aktif), privat/klasikal, modul, asistensi, praktis, sistematis, variatif, komunikatif, dan fleksibel.

Keunggulan dari metode Iqro' adalah seluruh penjuru Indonesia dan sebagian Negara ASEAN sudah menggunakannya, buku panduan mudah didapatkan dan harganya terjangkau, menerapan sistem CBSA, fleksibel, praktis, dan variatif. 
68 | Tsaqifa Taqiyya Ulfah, Muhammad Shaleh Assingkily, \& Izzatin Kamala

\section{DAFTAR PUSTAKA}

Budiyanto, Mangun. (2019). Biografi \& Pemikiran K.H. As'ad Humam Membaca AlQur'an. (Yogyakarta: Program Studi Manajemen Pendidikan Islam Fakultas Ilmu Tarbiyah dan Keguruan UIN Sunan Kalijaga).

Budiyanto, Mangun, dkk. (2008). Paduan Praktis Pengelolaan TKA-TPA, TKAL-TPAL, dan TQA, Cet. II. (Yogyakarta: Balai Litbang LPTQ Nasional Team Tadarus "AMM").

Budiyanto, Mangun. (1995). Prinsip-prinsip Metodologi Buku Iqro' (Cara Cepat Belajar Membaca Al-Qur'an). (Yogyakarta: Balai Litbang LPTQ Nasional Team Tadarus "AMM").

Budiyanto, Mangun, dkk. (2003). Ringkasan Pedoman Pengelolaan, Pembinaan dan Pengembangan Gerakan Membaca, Menulis, Memahami, Mengamalkan dan Memasyarakatkan Al-Qur'an (Gerakan M5A). (Yogyakarta: Balai Litbang LPTQ Nasional Team Tadarus "AMM").

Farkhan, Muhammad. (2019). “Penerapan Metode Iqro' pada Pembelajaran membaca Al-Qur'an di Kelas IV MI Islam Kartasura Tahun Ajaran 2018/2019” Skripsi, (Surakarta: IAIN Surakarta).

Hermawan, Didik. (2018). "Penerapan Metode Ummi dalam Pembelajaran Al-Qur'an" Profetika: Jurnal Studi Islam $19 \quad$ (1): 27-35. http://journals.ums.ac.id/index.php/profetika/article/view/7751/4445.

Humam, As'ad, dkk. (2001). Pedoman Pengelolaan, Pembinaan, dan Pengembangan Qur'an M3A, Cet. XII (Yogyakarta: Balai Litbang LPTQ Nasional Team Tadarus "AMM").

Humam, As'ad. (1990). Buku Iqro' Cara Cepat Mebaca Al-Qur'an, (Yogyakarta: Balai Litbang LPTQ Nasional Team Tadarus "AMM").

Ilyas, Yunahar. (2013). Kuliah Ulumul Qur'an, (Yogyakarta: ITQAN Publishing).

Kartika, Rika dan Nurman. (2018). "Pelaksanaan Gerakan Masyarakat Magrib Mengaji di Nagari Lubuk Basung Kabupaten Agam" Journal of Civic Education 1 (2): 141148. http://ice.ppj.unp.ac.id/index.php/ice/article/view/185.

Kulsum, Ummu. (2019). "Pendampingan Komunitas Guru Ngaji Sokolelah dengan Teknik Manajemen Sedekah Waktu Tahfidz Qur'an Juz 30 di Desa Sokolelah, Kec. Kadur, Kab. Pamekasan" Prosiding Seminar Nasional Hasil Pengabdian $\begin{array}{llll}\text { Masyarakat } 3 & \text { 124-126. }\end{array}$ http://proceeding.uim.ac.id/index.php/senias/article/view/304/275

Latifah, Hamim. (2018). Penerapan Metode Tsaqifa dalam Pembelajaran Baca Al-Qur'an di SMK Muhammadiyah Kajen Pekalongan Tahun Pelajaran 2017/2018, Pendidikan Agama Islam, Fakultas Agama Islam,Universitas Muhammadiyah Surakarta. 